\title{
Györgyi Horváth
}

\section{Women Authors with/without Gender Studies: the Gendered Regimes of Authority in Hungarian Literary Criticism Today*}

\begin{abstract}
While in contemporary Hungarian literature women authors are constantly emerging and make themselves much more visible than ever before, the gender bias underlying literary evaluations seem to remain nearly intact. In her study Györgyi Horvath discusses three aspects of the gendered regimes of authority in order to give deeper insights into how gender bias re-produces within the Hungarian context. First, she focuses on lists of literary prize winners and critical rankings of published works (showing how many women writers are present on such lists in absolute numbers and in what percentages, and how their numbers have changed over time). Secondly, she explores the practice of critique writing itself, by analyzing the book review pages in two literary journals between 2007 and 2009 focusing on cases when the issue of "gender" itself comes up in the rhetoric of critics trying to underpin their aesthetic judgments on a given work. And finally, she examines briefly the attitude of contemporary women writers towards Gender Studies. Horvath concludes that Gender Studies in Hungary has not contributed significantly to increasing the prestige of contemporary women writers, most of whom, in turn, do not want to be involved with Gender Studies or feminism at all. She also points out that at present in Hungary there is a general blindness in understanding how gender/power relations permeate aesthetic judgments.
\end{abstract}

Gender Studies in Hungary started only after the political changeover of 1989 with the first feminist essays being published in 1991 and 1993, written by Jolanta Jastrzebska and Steven Totosy de Zepetnek, respectively, while the first anthology of feminist literary criticism was edited by Judit Kádár in 1994. Since then, Gender Studies have become widely known in Hungarian academic life, even though its prestige is still somehow problematic. My aim in this study, however, is to focus on the question of what inroads, if any, Gender Studies, a field with its origins in academia, has made in the field of contemporary Hungarian literature, a field structured not by academics but by living authors, critics, editorial boards of literary journals, and literary prizes. The question remains what, if any, effect Gender Studies has had on the literary sphere outside the academy during the last two decades. It is telling that critics usually mark the year 2005 (and not the above date of 1991) as a symbolic starting date for the revival of Hungarian women's writing, the year when Éjszakai állatkert (Bódis, Forgács, and Gordon 2005), the first anthology of contemporary women writers was published. The gap between year 1991 and year 2005 nevertheless already marks a shift in time, a potential difference in the perception of Gender Studies. I shall therefore structure my paper around the following three questions: What is the reason of the delay between the reception of Gender Studies and 2005, the symbolic moment of the revival of Hungarian women's writing? What effect has Gender Studies had on the prospects and reputation of contemporary women writers? Is literary authority still gender-specific in Hungary and if it is then to what extent and how?

\footnotetext{
* The present article is an extended version of an earlier paper presented at an academic conference (Gender Issues in Contemporary Finno-Ugric Cultures) held at Groningen University, Netherlands, June $3^{\text {rd }}$, 2010 and published in v. 6 of Studia Fenno-Ugrica Groningana: Boode, Hanneke - Zsadányi Edit (eds.): Gender Perspectives on Hungarian and Finnish Culture. Proceedings of the Workshop Gender Issues in Contemporary Finno-Ugric Cultures (Maastricht: Shaker, 2011).
} 
In this study I shall discuss three aspects of the gendered regimes of authority in Hungarian literature today. First, I shall focus on lists of literary prize winners and critical rankings of published works - in short, things that clearly denote literary authority, showing how many women writers are present on such lists in absolute numbers and in what percentages, and how their numbers have changed over time. Secondly, I shall focus on the practice of critique writing itself, by analyzing the book review pages in two literary journals between 2007 and 2009. I am mainly interested in whether the scholarly term Gender Studies or even the issue of "gender" itself comes up in the rhetoric of critics trying to underpin their aesthetic judgments on a given work. I will look then for any term or content denoting Gender Studies or any gender related issue. And finally, I would like to examine briefly the attitude of contemporary women writers toward Gender Studies and feminism in Hungary. Let me first turn to the first aspect of the gendered regimes of authority in Hungary, that is, a gendered analysis of the list of literary prize winners and critical rankings of women writers. A literary prize is an obvious sign of literary prestige and respect, that is, it is a mark that a given interpretive community attributes high value to a given author or work. As such, a literary prize has the dual function of denoting and creating authority. Naturally, it does matter who gives the prize, what the prize is, and the justification for the prize. At present, the most prestigious literary award in Hungary is the Kossuth Prize, followed by the Attila József Prize, both of which replaced the Baumgarten Prize, which had been the most prestigious literary Prize before the Second World War. Although, in the case of most Hungarian literary prizes, complete lists of awardees are not available, certainly not retroactively for more than one or more decades, in the case of the Baumgarten and Attila József Prizes, complete list of winners are easily available, while in the case of the Kossuth Prize, only a partial list of winners can be publicly accessed. The following table shows how many women were among the winners of the above mentioned prizes, by decades:

\begin{tabular}{|c|c|c|c|c|}
\hline \multicolumn{2}{|c|}{ Prize } & $\begin{array}{c}\text { Number of } \\
\text { awardees }\end{array}$ & $\begin{array}{c}\text { Number of } \\
\text { women awardees }\end{array}$ & $\begin{array}{c}\text { Percentage } \\
\text { of } \begin{array}{c}\text { women } \\
\text { awardees }\end{array}\end{array}$ \\
\hline \multicolumn{2}{|c|}{$\begin{array}{c}\text { Baumgarten prize ('dij') and } \\
\text { reward ('jutalom') (1929-49) }\end{array}$} & 177 & 14 & $7.90 \%$ \\
\hline $\begin{array}{c}\text { Attila } \\
\text { József prize }\end{array}$ & $1950-59$ & 167 & 16 & $9.58 \%$ \\
\cline { 2 - 5 } & $1960-69$ & 89 & 9 & $10.11 \%$ \\
\cline { 2 - 5 } & $1970-79$ & 119 & 17 & $14.29 \%$ \\
\cline { 2 - 5 } & $1980-89$ & 101 & 12 & $14.88 \%$ \\
\cline { 2 - 5 } & $1990-99$ & 98 & 18 & $14.17 \%$ \\
\hline \multicolumn{2}{|l|}{$\begin{array}{l}\text { Kossuth prize (2002-2009-09) } \\
\text { (literary awardees only) }{ }^{3}\end{array}$} & 127 & 3 & $14.29 \%$ \\
\hline
\end{tabular}

The above table clearly shows a slow but continuous growth in the number of women among the awardees, with the percentage of women nearly doubling during eighty years, rising from $7.9 \%$ to $14.29 \%$. The $14.29 \%$ of prizes awarded to women roughly during the last decades also coincides with the percentage of women on the awardee lists of many other contemporary literary prizes, for example, the Tibor Déry Prize, Sándor Márai Prize, or Milán

\footnotetext{
${ }^{1}$ From Wikipédia. <http://hu.wikipedia.org/wiki/Baumgarten-d\%C3\%ADj>.

${ }^{2}$ Source: Petőfi Irodalmi Múzeum On-line Adattára.

<http://regi.pim.hu/Online/adattar/intezmenyek.php?doit=dijak\&mit=N\%E9v\&ertek=J\%F3zsef\%20Attila$\mathrm{d} \%$ EDj\&valt=pontos $>$.

${ }^{3}$ Source: Wikipédia. <http://hu.wikipedia.org/wiki/Kossuth-d\%C3\%ADj>.
} 
Füst Prize. ${ }^{4}$ This still relatively low representation of women, however, cannot be explained away by the still prevalent excuse that men become authors seven times more often than women do. Already in the 1860s women authors emerged in greatly increasing numbers (Fábri, 1996). Even if in the beginning of the twentieth century there were still fewer women authors eligible for awards, from the middle of the twentieth century citing the supposedly fewer numbers of women authors as an explanation for the low number of prize winners is, at the least, outdated. Important in the above data, however, is that the percentage of women awardees has not risen at all since the beginning of the 1970s, remaining stable at about 14\%, which makes it evident that there has apparently not been any sensitivity in the literary world to the extreme underrepresentation of women among the awardees, notwithstanding that in the meantime Gender Studies appeared in Hungarian academic circles.

Similarly, women authors also remain underrepresented on top lists and critical rankings of published books in Hungary. Let me consider first the example of Magyar Narancs, a left-wing periodical with a strong cultural slant, which in 2008 launched a special top list of Hungarian-language books published in the previous months, ${ }^{5}$ an initiative that was unique inasmuch as it was based on the votes of acclaimed literary critics, and not on the sales numbers of bookstores. In the rating system established by Magyar Narancs, every two to four months the same group of thirty critics chose what they consider to be the best eleven works published during the previous half year. From the start the emphasis was on literary rather than on theoretical works, and eventually the list was subdivided into Hungarian and world literature. From February 2008 until December 2009 critics awarded 4,545 points altogether to Hungarian literary (or theoretical) works, from which 478 points, that is $10.52 \%$ was given to woman-authored texts, a percentage more or less the same we have seen in the case of literary prizes.

In November 2008 Magyar Narancs made some changes in personnel among the critics, and at the same time raised the number of voting women, so that while in February only 7 out of the 30 critics were women, by November 13 out of 36 were, that is to say their percentage increased from $23.33 \%$ to $36.11 \%$. Since it was clearly prestigious to get into the narrow circle of the best 30 or 36 critics, the change in November 2008 meant an explicit recognition of the authority of women as critics. However, considering the fact that from November 2008 the number of women chosen on the lists did not increase, this change in the number of women critics has not had any effect upon the authority of women as literary authors. While before November 2008 women writers were given 212 points out of 1924 (that is, $11.09 \%$ ), between November 2008 and December 2009 they were given 266 out of 2621 points (that is, $10.15 \%$ ). In short, raising the number of female members on the jury did not raise the number of women who were chosen on the lists.

It is worth mentioning that while the number of women on the jury was raised in November 2008, the number of Gender Studies experts was cut, falling from 7 out of 30 to 6 out of $36 .{ }^{6}$ It is debatable whether the list results would have changed if this number had not been cut because there is no forum in the field of contemporary Hungarian literature (a prize, a journal or a list) where Gender Studies experts prevail, and which thus could serve as a reference point for comparisons and conclusions. ${ }^{7}$

\footnotetext{
${ }^{4}$ Tibor Déry prize, 2000-2009: 28 awardees, 3 of them are women (10.71\%) (without taking into consideration Prizes awarded to critics and literary translators). Sándor Márai prize, 1996-2009: 29 awardees, 3 of them are women (10.34\%). Milán Füst prize, 1990-2007: 29 awardees, 3 of them are women (10.34\%) (without taking into consideration Prizes awarded to translators). Source: Wikipédia.

5 "Minimum tizenegyes!". Magyar Narancs, 2008. február 28.

${ }^{6}$ See "Minimum tizenegyes!". Magyar Narancs, 2008. február 28.; ”A közelítő tél - Minimum tizenegyes! - a Magyar Narancs irodalmi sikerlistája". Magyar Narancs, 2008. november 27.

7 In a special sense the webjournal Irodalmi Centrifuga edited by Agáta Gordon and Kriszta Bódis (<http://elofolyoirat.blog.hu〉), could serve as such a reference point, but their status as „Gender Studies experts”
} 
Having seen the quantitative underrepresentation of women among Hungarian literary Prize awardees, let me now turn to the qualitative analysis of literary critique writing. Let me first consider Jelenkor, a Hungarian literary journal where well-known authors and critics publish their works. Between January 2007 and December 2009, Jelenkor published critiques of altogether 139 Hungarian (literary or theoretical) works, 21 of which were womanauthored $(15.11 \%)$. The following table is based on the review section of Jelenkor between 2007 and 2009, paying special attention to whether any signifiers of femininity come up in the rhetoric of critics when they underpin their aesthetic judgments on woman-authored texts, and also whether there is any reference to Gender Studies specifically or to feminism more generally.

\begin{tabular}{|c|c|c|c|c|}
\hline \multirow{2}{*}{$\begin{array}{l}\text { The number } \\
\text { of critiques } \\
\text { written on } \\
\text { woman- } \\
\text { authored texts }\end{array}$} & \multicolumn{2}{|c|}{ On literary texts } & \multicolumn{2}{|c|}{ On theoretical texts } \\
\hline & $\begin{array}{l}\text { "Non-gender } \\
\text { related" books }\end{array}$ & $\begin{array}{l}\text { "Gender- } \\
\text { related books", }\end{array}$ & $\begin{array}{l}\text { "Non-gender } \\
\text { related books" }\end{array}$ & $\begin{array}{l}\text { "Gender- } \\
\text { related books" }\end{array}$ \\
\hline 21 & 12 & 4 & 2 & 3 \\
\hline $\begin{array}{l}\text { Signifiers of } \\
\text { femininity } \\
\text { underpinning } \\
\text { aesth. } \\
\text { Judgment }\end{array}$ & 3 & 0 & 0 & 0 \\
\hline $\begin{array}{l}\text { Reference to } \\
\text { feminism / } \\
\text { Gender Studies }\end{array}$ & 1 & 4 & 0 & 2 \\
\hline
\end{tabular}

Among the twelve critiques on woman-authored non-gender related books, there are only three critiques that make use of signs of femininity in order to underpin aesthetic judgments. While in my perception, two of the three critiques making use of signifiers of femininity are quite innocent, free of gender bias (Görföl 2007; Sántha 2007), the third review in which József Sántha criticizes Judit Ágnes Kiss' volume of poetry seems problematical (Sántha 2008). Sántha, having linked Kiss' volume with hysteria and having stated that "the sincere or mannered scandalous-tragical poems about the problem of femininity play a notable part" in the volume, summarizes his opinion of the book in the following way: "Only time will tell whether the volume will be successful. [It is not clear yet] whether Ágnes Judit Kiss will be able to lie herself through to truth [of credible poetry], or whether she gets bogged down in small successes, within the narrow circle of a flourishing, self-admiring feminist bravery" (Sántha 2008, 224). ${ }^{9}$

Within the same three-year period as Jelenkor published the above discussed critiques, Litera, the number one Hungarian literary e-journal, produced nearly the same number of book reviews as Jelenkor, that is, 193 book critiques within three years. Of the 193 books reviewed thirty-two were woman-authored (16.58\%). Out of the thirty-two, Péter I. Rácz's

remains problematic. The conflict between Gender Studies experts and women writers promoting "women's perspective" in contemporary Hungarian literature will be discussed later on.

8 "Gender-related books", that is two anthologies of contemporary women writers (Éjszakai állatkert and Szomjas oázis), where the two critiques written on them plus the public debate provoked by the latter make up to the number 4. I use the term "gender-related book" for books that make use of the insights of Gender Studies, while the term "non-gender related book" marks books that do not problematize the issue of gender.

${ }^{9}$ In Hungarian: "Hogy ez mire lesz elég, még nem tudhatjuk. [Még nem világos, hogy] Kiss Judit Ágnes keresztül tudja-e majd hazudni magát az igazságig, vagy megreked a kis sikerekben, szük körökben tenyészö, öntetszelgő feminista bátorságnál”. 
critique on the semi-autobiographical novel of Ildikó Szilágyi-Nagy was the only one that, similarly to József Sánta's, deliberately misused the signs of femininity, calling the womanprotagonist a "culture cunt" [kultúrpicsa] in order to illustrate the aesthetic deficiencies of a woman-authored texts. (Rácz 2008). While I do not have exact data about the review pages of other literary journals, I see more or less the same rate as above between man- and womanauthored texts reviewed in them. Beyond the numbers, however, one can conclude that, although critics do abuse signifiers of femininity to devalue women's literary texts, such instances are becoming less common.

As we have seen, there are very few misuses of the signifiers of femininity in the argumentation part of literary critiques, the description of woman-authored literary works in book reviews readily feature signifiers of femininity, contrary to critiques written on maleauthored texts, where the signifiers of masculinity are hardly present at all. While womanauthored texts usually can not avoid being described as woman-authored and often judged on the basis of what kind of femininity the critic thinks the text tries to represent or promote, man-authored books or volumes are hardly perceived by their critics as having a gender or a gendered author at all. This inequity denotes that, contrary to the unmarked masculinity of men writers, femininity is still a marked identity in the regimes of literary authority. To give an example, between 2007 and 2009 there was only one critique in Jelenkor, Miklós Győrffy's review of Endre Kukorelly's sexually charged picaresque novel, Ezer és 3 [Thousand and 3], where signifiers of masculinity played an important part in the description of a book (Györffy 2009). Here Györffy perceives the "masculine" and "macho" nature of the novel as a clear sign of the fact that what is at stake for Kukorelly is the critique of feminism and gender theories, where the latter, at least according to Györffy, "consider the borderline between men and women relativistic, nearly optional, and professes that gender, at least from social perspective, is a matter of free choice". ${ }^{10}$ Implicitly, however, Györffy criticizes the novel for its outright machoism and for the protagonist's objectifying behavior towards his female sexual partners. That is, although Győrffy finds Kukorelly's novel problematical for more or less the very same reasons any gender expert would, he refuses to take up any perspective even remotely reminiscent of the perspective of feminism. Instead, he distances himself from gender studies through a sophisticated strategy of power in order to avoid giving any credit to such low prestige discipline as Gender Studies is in Hungary.

Györffy's description of Kukorelly's novel already ventures into an explicit (mis)representation of Gender Studies, which leads us to a number of references gender theories received in the review pages of Jelenkor between 2007 and 2009. In these years the journal published writings on quite a few "gender-related books", and usually called upon well-known gender experts to critique them; only one book out of the five was reviewed by a non-expert (Gajdó, 2008). Contrary to the apparently simple case of "gender-related books" being reviewed by gender experts with the mostly adequate use of concepts of gender theories, ${ }^{11}$ when Gender Studies crosses the border between the academic sphere of literary studies and the sphere of contemporary literature, there always seems to be a conceptual disturbance taking place. The passages quoted from Sántha and Györffy already show this conceptual mess: the subject of the critique is a literary work but the critics arbitrarily link it to Gender Studies or feminism, putting the latter in a negative context. According to Sántha, feminism equals "small successes" and "the narrow circles of a flourishing, self-admiring feminist bravery", while according to Győrffy, Gender Studies professes that gender "is a matter of free choice". While in Sántha's words one can easily identify the everyday bias

\footnotetext{
${ }^{10}$ In Hungarian: "a gender-elméletek [...] viszonylagosnak, szinte tetszőlegesnek tekintik a férfiak és nők közti határvonalat, és azt vallják, hogy a nem, társadalmi szempontból legalábbis, szabadon választható".

${ }^{11}$ Books marked as "gender-related books" in the table: Éjszakai állatkert and Szomjas oázis (literary texts), Séllei 2007, Darabos 2008, and Borgos 2007 (theoretical texts).
} 
against feminism, Győrffy's statement falls in the category of being "scientifically misleading" and as such represents a more sophisticated form of prejudice, since his terse assertion about Gender Studies' founding insights is clearly mistaken. What is most worrying, however, is that neither literary critics like Sántha or Győrffy, nor the editors (and readers) of Jelenkor, are able to question these misleading and sexist assertions. Clearly neither the critics nor the editors are gender experts. There is a lack of commentaries or corrections to the assertion that gender issues are apparently the task of only a "narrow feminist circle" in Hungary.

In order to get a more detailed picture about how Gender Studies is perceived by the different players in contemporary Hungarian literature, it can prove useful to take a look also at how the relation of gender and literature is interpreted by those who are often considered the "natural allies" of gender experts, that is, women writers themselves. In 2008, a short dispute broke out in the eleventh issue of Jelenkor which clearly demonstrates that gender experts from academic circles and literary authors promoting gender equality in literature can differ greatly both in their understanding of Gender Studies, feminism and on how the literary prestige of women writers could be raised. The dispute broke out when Zsuzsa Forgács, editor of the groundbreaking anthology Éjszakai állatkert and Szomjas oázis (on which see Rachel Miller's article in this volume) criticized gender expert László B. Sári's critique, published a couple of months earlier, of the latter volume, with Sári responding to Forgács briefly in the said issue. In accordance with the insights of Gender Studies, Sári starts by pointing out that the evaluation of women's writing has an "aesthetical and political" character and importance. Although he criticizes some of the traits of Szomjas oázis, he clearly engages himself in favor of the project of women's writing in Hungary. Ultimately, it is precisely his faithful engagement with the project that makes him dismiss the anthology as failing to take full advantage of the opportunity it had in promoting women's writing in Hungary.

In response to Sári's critique of the anthology, Forgács focuses on the negative elements of the review. She tries to defend her position as an editor by claiming how much she worked on each of the texts and stating that "our volumes [...] have a clear fecundating effect, creating new values within our literature [and], as has already been noticed by many critics since Éjszakai állatkert was published, far more women-authored texts have been published than earlier" $(1302)^{12}$. Unfortunately, Forgács's assertion of the positive influence of this anthology is hard to verify. The most important part in her argumentation, however, is where she distances herself from feminism, stating that "it is absurd to look for whether the guidelines of feminism or the literature that Sári claims as women's literature are presented in our volume [because] while creating a literary work or editing a literary book, we cannot take ideological considerations as a starting point" (1303). ${ }^{13}$ That is, taking up a clearly antifeminist position, Forgács claims that it is not feminism but "women-centeredness" that is the basic concept of her anthology:

"I will not edit out authors and texts from the book only because, according to Sári's feminist, ideological point of view they do not fit in. What I want is to present female world-views as they are here and now without distorting them according to what these world-views are supposed to be in our critic's or anyone else's views. It is not by accident that, as I have emphasized many times and in many places, that I consider the books I edit first of all women-centered, and that I have been resolutely trying to avoid the category of "women's writing". Our anthologies are books that

\footnotetext{
12 In the original Hungarian: "köteteink [...] kifejezetten megtermékenyítő, értékteremtő hatással vannak irodalmunkra. Mint azt már sok kritikus és irodalmár is jelezte, az Éjszakai állatkert óta jóval nagyobb számban jelentettek meg írónőktől köteteket Magyarországon, mint korábban”.

13 In the original Hungarian: "a feminizmust, illetve a Sári által nőirodalomnak nevezett irodalom irányelveit is abszurd számon kérni a köteten. Véleményem szerint, irodalmi müvek alkotásánál, illetve irodalmi könyvek szerkesztésénél nem indulhatunk ki ideológiai megfontolásokból”.
} 
describe our world from the perspective of real women. In contrast to Sari's prerequisites, I was inspired to launch this book series not by feminist principles, as Sári assumes, but by a LACK. Very few woman-centered books or woman protagonists assisted my own growing up". (1302-3)

From Forgács' comments, it seems that she either cannot or does not want to see any kind of similarity or relation between women-centeredness, feminism and Gender Studies. Forgács also seems to hold on desperately to the illusion that the aesthetic sphere can be absolutely purified from ideology when stating that "I think that while creating a literary work or editing a literary book, we cannot take ideological considerations as a starting point". She turns against feminism either because she deeply believes that literature can and should be free from any ideology or, more probably, because not keeping a distance from (feminist) ideology and the politicization of aesthetical values is still a bigger "mistake" in the contemporary literary field than it is in academic departments, where Gender Studies usually resides.

In an essay written in 1997 and an interview from 2004 with another Hungarian woman author, Zsófia Balla, we can observe an intriguing shift from outward sympathy towards gender the sensitive perspective to the same reluctance to side with feminism and ambivalence towards the issue of women's writing as we have seen in Forgács' way of looking at women in literature. In her 1997 essay, Balla overtly touches upon the issue of how the marginal status of women writers persistently reproduces itself within the Hungarian literary scene by giving an expressive example of how the whole process works:

"I do not want to play down the fact that we do live in a patriarchal society and this has many consequences. To give an example, it can easily occur that a colleague organizing a literary event fails to invite any women even though we are talking about a situation when people are on the same level of talent and achievement. He does not leave them out intentionally; they just do not come into his mind simply because he is not socialized into paying attention to the gender of his colleagues and gender issues are not in the center of private or public attention. When at the end of 1995 an anthology of literature in seventeen languages came out, out of the fifty-five authors published only two were women, a telling example of forgetfulness and absentmindedness which demonstrates clearly that women authors do not "exist" and that their works do not count as literature. There is also an anecdote about the non-existence of Hungarian women writers, according to which during an author-reader meeting a member of a delegation of foreign authors asked whether there were any women writers in Hungary? The acclaimed Hungarian writers just shrugged in response and spread their arms regretfully. Ágnes Nemes Nagy [a female author of high prestige], by that time already a classic of Hungarian literature, was sitting in the same room. I do not know if that was when she left. What is interesting in all this is that the slighting is not conscious but it is intentional. If he realizes it, he might even apologize. Yet the next time an event is organized or a swaggering list of best authors compiled, woman authors in strong competition with any male authors will surely be ignored again". ${ }^{15}$

\footnotetext{
${ }^{14}$ In the original Hungarian: "Nem fogok kihagyni szerzőket és szövegeket a könyvből, csak azért, mert Sári B. szerint feminista, ideológiai szempontból nem odavalóak. Én az itt és most női világlátásait szeretném bemutatni, és nem azt, amilyennek kritikusunk vagy mások szerint ezeknek lenniük kellene (müssen). Nem véletlen, hogy sok helyen és sokszor hangsúlyozom, az általam szerkesztett könyveket elsősorban nőszempontúnak tartom, és kifejezetten kerülni igyekszem a "nőirodalom" kategóriát. Antológiáink olyan könyvek, amelyek a létező nő(k) felől írják le világunkat. Szemben Sári előfeltevéseivel, engem nem a feminizmus elvei ösztönöztek a sorozat elindítására, hanem a HIÁNY. Rendkívül kevés nőszempontú könyv és főhős segítette ugyanis felnövekedésemet”.

15 In Hungarian: "Nem akarom elhallgatni azt, hogy férfivilágban élünk. Ennek sokféle következménye van. Például az is előfordulhat, hogy - azonos mérvü tehetségről, teljesítményről lévén szó -, adott esetben az irodalmi estet szervező kollégá(k)nak nem jut eszébe egyetlen nőnemű írótársa sem, akit meghívna. Nem szándékosan hagyja ki a nőket; eszébe sem jutnak. Nem erre van szocializálva, ez nincs a köz- és magántudatban. A 95-ös év végén megjelent 17 nyelvü irodalmi antológiában az 55 szerzőből 2 nő. Beszédes feledékenység és szórakozottság, amely arról szól, hogy ezek nincsenek, nem számítanak irodalomnak. Van egy anekdota is, mely
} 
In the above passage Balla gives a brief but accurate analysis both of how patriarchy operates in Hungarian literature and of the psychic processes through which patriarchy constantly reproduces itself. Seven years later, however, when answering an interviewer about how she relates to the question fashionable nowadays concerning whether there is such a thing as women's writing, Balla says:

“There is no such thing as separate women's writing. Whenever I hear this term, it always reminds me of a kind of dilettantism and of scribbling housewives. Naturally, I have no objection to their scribbling, obviously this resolves their psychological problems. It might even happen that they produce talented and engaging pieces. But I would not mistake these for literature. [...] There [is] a huge difference between the two types of writing. I simply do not have the above mentioned housewife- or amazon-like ideology within me". ${ }^{16}$

Although later in the same interview, Balla again touches on the issue of social inequity between men and women in Eastern European countries, stating that "Hungarian society has a particularly macho character," she never acknowledges explicitly that such a "macho" society does logically exercise a severe influence on the evaluation of literary works or the way the aesthetic sphere is set up. This even while admitting that in order to become a writer, one needs to have a certain level of financial and existential independence most women can hardly achieve in Hungarian society, "A piece of art is good or it is not a piece of art. It has nothing to do with gender" she states in 2007 effectively reproducing the very stereotype about women writers she described (and criticized) so thoroughly in her 1997 essay in which she pointed out that "women authors do not exist, their works do not count as literature".

In the above quoted excerpts both Forgács and Balla take for granted that the relation between ideology and aesthetic values can only be oppositional and that the aesthetic sphere could and should be absolutely purified from ideologies. Although their general attitude towards the issue of women's writing is highly different, with Forgács being regarded as a kind of amazon-like, women-promoting ideological figure that many people try to distance themselves from and Balla usually staying away from gender debates, their opinion (or the rhetoric they apply) is representative of how the vast majority of Hungarian women writers still think about Gender Studies and feminism: rejecting the labels "women writer" or "women's writing" because they feel that accepting them would mean admitting that their works are "ideological" and therefore fail to meet higher aesthetic standards.

To conclude, despite the fact that Gender Studies arrived to Hungary in the early 1990 s, the number of women writers acknowledged by critics and prize-givers has not risen at all in the last four decades. Among the works that are awarded literary prizes, appear in review pages of literary journals, or figure on the rankings of elite literary works, only 14$15 \%$ have a female author. The fact that this is the same percentage that gets reproduced in most segments of the contemporary Hungarian literary field denotes the stability and deeprootedness of patriarchal ideology. Femininity, in contrast to the unmarked masculinity of

szerint a hazánkba látogató íróküldöttség tagja megkérdezte a felolvasóesten, hogy itt nincsenek női írók? Mire a jónevü magyar írók sajnálkozva tárták szét a karjukat. Nemes Nagy Ágnes, akkor már a magyar irodalom klasszikusa, ott ült a teremben. Nem tudom, nem ekkor ment-e ki. Mindebben az az érdekes, hogy a mellőzés nem tudatos, de szándékos. Ha eszébe jut a kollégának, akár bocsánatot is kér. De a következő rendezvénykor, vagy egy kakaskodó fölsorolásban megint elfelejti a valóban konkurenciát jelentő kolleginát."

16 In Hungarian: "Külön női irodalom nem létezik. Amit annak neveznek, az engem mindig egyfajta dilettantizmusra emlékeztet, írogató háziasszonyok jutnak eszembe. Természetesen semmi kifogásom az ellen, hogy írogassanak, ezzel nyilván megoldódnak lelki problémáik. Még az is lehet, hogy tehetséges vagy rokonszenves írásműveket szorgoskodnak össze. De ezt nem téveszteném össze a magas irodalommal. [...] Hatalmas különbség [van] az írás kétfajta módja között. Bennem az elöbb említett háziasszonyi vagy amazon nőideológia nincs meg". 
men writers, still marks identity in the regimes of literary authority. Although only a few critics abuse signs of femininity to illustrate the aesthetical discrepancies of the literary work at issue, which is a positive development, the field of contemporary Hungarian literature is still structured by the illusion that aesthetical values can and should be free of politics. From this perspective it becomes more understandable why the application of Gender Studies to contemporary literary works so frequently ends up being problematic fraught with conceptual discrepancies, negative stereotypes, reticence or resistance. But is it possible to promote Hungarian women's writing without Gender Studies? It seems that Gender Studies has not contributed significantly to increasing the prestige of contemporary women writers, most of whom, in turn, do not want to be involved with Gender Studies or feminism at all. However, I would still like to draw attention to Zsuzsa Rakovszky's answer to a question raised by Litera at the end of 2009: "I am sure that formerly I would have said that there is no such thing as separate women's literature, only literature, but nowadays I see that there are aspects of the [gender] problem which affect me [as a woman author]". ${ }^{17}$

\section{Works Cited}

Balla, Zsófia. 1997. Nőirodalom, mi az? Magyar Lettre Internationale 24 (Fall): <http://www.c3.hu/scripta/lettre/lettre24/14balla.htm>.

Balla Zsófia. 2004. "Egy mü vagy jó, vagy nem mü.” Balla Zsófia a női írásról, díjakról, kritikáról, fordításról. Karafiáth Orsolya interjúja. The website of the Hungarian Ministry of National Resources (Nemzeti Erőforrás Minisztérium), December 1st, 2004: $<$ http://www.nefmi.gov.hu/kultura/interju/egy-mu-jo-nem-mu-balla .

Bódis, Kriszta, and Forgács, and Gordon (eds.). 2005. Éjszakai állatkert. Antológia a nöi szexualitásról. Budapest: Jonathan Miller.

Fábri, Anna. 1996. "A szép tiltott táj felé." A magyar irónők története két századforduló között. 1795-1905. Budapest: Kortárs.

Forgács, Zsuzsa Bruria (ed.). 2007. Szomjas oázis. Antológia a női testről. Budapest: Jaffa.

Forgács, Zsuzsa Bruria. 2008. Válasz Sári B. Lászlónak. Jelenkor 11: 1302-03.

Görföl, Balázs. 2007. Csukott szemü boldogság: Szabó T. Anna: Elhagy”. Jelenkor 7-8: 82629.

Győrffy, Miklós. 2009. Aktus-orientált párkapcsolatok: Kukorelly Endre: Ezer és 3 nő. Jelenkor 12: 1347-50.

Jastrzebska, Jolantha. 1991. Archaizálás és intertextualitás: Csokonai Lili: Tizenhét hattyúk. Irodalomtörténeti Közlemények 1: 48-62.

Kádár, Judit (ed.). 1994. Feminista nézőpont az irodalomtudományban. Helikon 4.

Rácz I., Péter. 2008. "A forrókásának írom”: Szilágyi-Nagy Ildikó: Valami jó testnyílás. Litera, február 11: <http://www.litera.hu/hirek/\%E2\%80\%9Ea-forrokasanakirom\%E2\%80\%9D>.

Rakovszky, Zsuzsa. 2009. Alkati jogon. Jánossy Lajos interjúja. Litera november 26: $<$ http://www.litera.hu/hirek/alkati-jogon>.

Sántha, József. 2007. A szép és az okos: Berniczky Éva: Méhe nélkül a bába. Jelenkor 11: 1229-31.

Sántha, József. 2008. Atlasz kisasszony sirámai: Kiss Judit Ágnes: nincs új üzenet. Jelenkor 2: 221-24.

Sári B., László. 2008. Alkalmi írás a nőirodalom állásáról: Szomjas oázis. Jelenkor, 9: 99599.

\footnotetext{
${ }^{17}$ In Hungarian: „régebben biztosan azt mondtam volna, hogy nincs külön női irodalom, csak irodalom --, de mostanában úgy látom, van olyan vonatkozása a problémának, amelyik érint.”
} 
Sári B., László. 2008. Válasz Forgács Zsuzsa Bruriának. Jelenkor 11: 1304.

Sonnevend, Júlia. 2007. Let's Talk About Sex, Baby! Éjszakai állatkert. Antológia a női szexualitásról. Jelenkor 9: 960-63.

Totosy de Zepetnek, Steven. 1993. Kaffka Margit prózája: az irodalmi feminizmus kezdete Magyarországon. Régi és új peregrináció. Magyarok külföldön, külföldiek Magyarországon, eds. Békési, Imre és mtsai. Vol 2, Budapest-Szeged: Nemzetközi Magyar Filológiai Társaság - Scriptum Kft. 1185-94. 